\title{
PROFIL INDUSTRI RUMAH TANGGA TAHU TEMPE “X” DI KELURAHAN BAHU KECAMATAN MALALAYANG
}

\author{
Sinike Hara \\ Ribka M. Kumaat \\ Paulus A. Pangemanan \\ Mex L. Sondakh
}

\begin{abstract}
ABSRACT
This study aims to determine the profile of Tahu Tempe industry in Bahu District of Malalayang. This research was conducted for 3 months starting from preparation to reporting. Place of research in Bahu District of Malalayang. The data used are primary data and secondary data. Primary data were obtained through direct interviews with business owners using a questionnaire. Secondary data was obtained from Department of Industry (Dinas Perindustrian) of Manado City. Data were analyzed by using descriptive analysis where the data were presented in table and then discussed descriptively. The results showed that the industry of Tahu Tempe " $X$ " in Bahu District of Malalayang earned a profit of Rp14.661.667 per month. This profit is obtained by subtracting revenue of Rp59,250,000 per month with total cost of Rp44,588,333 per month.
\end{abstract}

Keywords: profile, home industry, tofu tempe, Malalayang Sub-district, Manado City

\begin{abstract}
ABSTRAK
Penelitian ini bertujuan untuk mengetahui profil industri Tahu Tempe di Kelurahan Bahu, Kecamatan Malalayang. Penelitian ini dilaksanakan selama 3 bulan mulai dari persiapan hingga penyusunan laporan. Data yang digunakan adalah data primer dan data sekunder. Data primer diperoleh melalui wawancara langsung dengan pemilik usaha dengan menggunakan kuesioner. Data sekunder diperoleh dari Dinas Perindustrian Kota Manado. Data dianalisis dengan menggunanakan analisis deskriptif dimana data disajikan secara tabelaris dan kemudian dibahas secara deskriptif. Hasil penelitian menunjukan bahwa Industri Tahu Tempe " $X$ " di Kelurahan Bahu Kecamatan Malalayang memperoleh keuntungan sebesar Rp.14.661.667 per bulan. Keuntungan ini diperoleh dengan mengurangkan penerimaaan sebesar Rp.59.250.000 per bulan dengan biaya total sebesar Rp.44.588.333 per bulan.
\end{abstract}

Kata kunci: Profil, Industri, Rumah Tangga, Tahu, Tempe, Kecamatan Malalayang, Kota Manado 


\section{PENDAHULUAN}

\section{Latar Belakang}

Dewasa ini kesempatan dan persaingan di sektor formal sudah sangat sulit, perbandingan lapangan kerja yang tersedia dengan tenaga kerja yang ada sudah tidak seimbangan lagi. Oleh karena itu salah satu alternatif adalah dikembangkan usaha-usaha ekonomi dalam masyarakat yang bersifat pada karya. Bentuk-bentuk usaha pada karya sebenarnya sudah banyak di geluti oleh masyarakat. Akan tetapi karena kurangnya modal atau managemen yang kurang baik, sehingga menyebabkan usaha-usaha seperti ini berhenti di tengah jalan. Salah satu bentuk usaha pada karya yang mulai banyak dikembangkan masyarakat adalah industri rumah tangga Tahu Tempe. Menurut Amang (1996) hal ini tercermin dari banyaknya permintaan akan kedelai dari tahun ke tahun. Meningkatnya permintaan disebabkan karena komoditas ini mengandung banyak protein nabati yang tinggi, sumber lauk, vitamin dan mineral sehingga kalau stoknya tersedia cukup,maka komoditas ini akan mampu memperbaiki gizi masyarakat melalui konsumsi kedelai segar maupun melalui konsumsi kedelai olahan seperti tahu, tempe, tauco,dan kecap.

Hal yang menarik dari keberadaan industri tahu dan tempe adalah skala industrinya yang kebanyakan masih berupa industri kecil dan menengah yang berproduksi dengan metode tradisional, padahal daya beli masyarakat untuk produk ini relatif tinggi. Tahu dan tempe memiliki peranan yang penting, yaitu sebagai alternatif lapangan pekerjaan serta sebagai sumber kontribusi pendapatan keluarga. Kendala pengembangan industri kecil dapat disebabkan oleh faktor kemampuan yang bersifat alamiah (mental dan budaya kerja), tingkat pendidikan, sumberdaya manusia, terbatasnya keterampilan, keahlian, keterbatasan modal, informasi pasar, volume produksi yang terbatas, mutu yang beragam, penampilan yang sederhana, infrastruktur, peralatan yang usang, beberapa kebijakan dan tingkah laku dari pelaku bisnis yang bersangkutan (Hubies,1997). Kandungan atau zat-zat gizi yang terdapat dalam kacang kedelai dapat dilihat pada Tabel 1.

\section{Tabel 1. Kandungan zat-zat makanandalam} kedelai

\begin{tabular}{lcc}
\hline Unsur-unsur & Kedelai Putih & $\begin{array}{c}\text { Kedelai } \\
\text { Hitam }\end{array}$ \\
Zat Makanan & & 14,05 \\
Air & 13,75 & 40,40 \\
Protein & 41,00 & 19,30 \\
Lemak & 15,80 & 14,10 \\
Karbohidrat & 14,82 & 5,25 \\
Mineral & 5,25 &
\end{tabular}

Sumber : AAK, 1990

Diperkirakan kebutuhan kedelai untuk bahan baku industri rumah tangga Tahu dan Tempe mencapai 80 persen dan sisanya untuk kebutuhan ternak dan konsumsi rumah tangga. Kota Manado dewasa ini terus menggalakan sektor industri untuk menopang meningkatan pendapatan dan kesejahteraaan masyarakat lewat sektor industri kecil. Dengan adanya penggalakan tersebut, industri Tahu dan Tempe mempunyai prospek pengembangan yang cukup besar dan ini di tunjang oleh ketersediaab bahan baku yaitu kedelai, sumber daya manusia (TK), kesempatan berusaha dan peluang pasar yang cukup terbuka. Makin meningkatnya industri kecil dan rumah tangga untuk hasil-hasil pertanian yang ada di Kota Manado memperlihatkan bahwa masyarakat sudah mulai menyadari bahwa hasil-hasil pertanian yang dihasilkan harus ada pengolahan lebih lanjut untuk mendapatkan nilai tambah dari hasil pertanian tersebut.

Industri tahu dan tempe di Kota Manado merupakan usaha kecil di mana status pemiliknya yaitu usaha milik sendiri sehingga dapat di kategorikan pada industri kecil. Mendirikan suatu industri tahu dan tempe para pengusaha harus mendapatkan " tanda daftar Industri" (TDI) dari Departemen Perindustrian dan Perdagangan Kota Manado dengan syarat telah memenuhi kriteria-kriteria tertentu seperti lokasi industri, surat keterangan Lurah mengenai usaha tahu atau tempe dan mengisi formulir mengenai usaha yang akan di keluarkan izinnya. tanda daftar industri ini merupakan surat izin usaha yang berlaku tanpa 
batas waktu. Industri tahu tempe $\mathrm{X}$ berada di Kelurahan Bahu Kecamatan Malalayang, perkembangan industri tahu tempe ini sudah berkembang cukup lama. Dan pengelola (pemilik) industri $\mathrm{X}$ adalah bapak Anwar, umur 40 tahun pendidikan terakhir SMA, pemilik juga terlibat langsung yaitu mengawasi proses produksi dan sebagai penanggung jawab terhadap semua keputusan dalam setiap kegiatan produksi. Selain memberikan manfaat bagi pengrajin sebagai sumber nafkah keluarga, dalam perkembangannya memberikan manfaat bagi masyarakat sekitar karena maenciptakan lapangan kerja maka peneliti tertarik untuk melihat keadaan "Profil Industri tahu tempe X".

\section{Rumusan Masalah}

Berdasarkan latar belakang yang telah diuraikan di atas maka masalah dalam penelitian ini adalah bagaimana profil industri Tahu dan Tempe di Bahu Kecamatan Malalayang.

\section{Tujuan Penelitian}

Penelitian ini bertujuan untuk mengetahui profil industri Tahu Tempe di Bahu Kecamatan Malalayang.

\section{Manfaat Penelitian}

1. Bagi para pengrajin tahu tempe, merupakan bahan masukan dalam mengelola dan mengembangkan usahannya.

2. Bagi kalangan akademisi, merupakan bahan referensi untuk meneliti lebih lanjut dalam rangka pengembangan sektor industri kecil.

\section{METODOLOGI PENELITIAN}

\section{Waktu dan Tempat Penelitian}

Penelitian ini dilaksanakan selama 4 bulan mulai dari persiapan hingga penyusunan laporan tempat penelitian Kelurahan Bahu Kecamatan Malalayang.

\section{Metode Pengumpulan Data}

Data dikumpulkan dengan wawancara kepada responden dengan menggunakan daftar pertanyaan (kuesioner). Data yang digunakan dalam penelitian ini adalah data primer dan data sekunder. Data sekunder diperoleh atau di ambil dari Dinas Perindustrian Kota Manado.

\section{Metode Pengambilan Sampel}

Studi kasus industri Tahu tempe $\mathrm{X}$ di Kelurahan Bahu Kecamatan Malalayang Kota Manado.

\section{Konsep Pengukuran Variabel}

Variabel yang akan diukur dalam penelitian ini adalah

1. Karakteristik Responden :

- pendidikan : di lihat dari tingkatan (Tidak sekolah, tamat SD,tamat SM,tamat SMA dan sederajat)

- Jenis usaha: Apakah usaha tersebut merupakan pekerjaan pokok atau sampingan

- Lama usaha: berapa lama usaha tersebut di jalankan (tahun)

- Jumlah tenaga kerja: berapa jumlah tenaga kerja dalam keluarga dan luar keluarga

- Status karyawan : apakah status kariawan dari dalam keluarga atau di luar keluarga

- Upah, Karyawan di upah dalam Harian, Mingguan atau Bulanan (Rp).

2. Pengadaan Bahan Baku Meliputi :

- Sumber bahan baku: sumber pembelian bahan baku (dari agen )

- Jumlah bahan baku : bahan dasar yang tersedia dan di pakai untuk proses produksi dinyatakan dalam (Kg/bulan).

- Harga bahan baku : harga beli kedelai dinyatakan dalam $(\mathrm{Rp} / \mathrm{Kg})$.

3. Produksi

- volume produksi yaitu, banyaknya jumlah produksi tahu tempe yang di hasilkan dinyatakan dalam (unit/bulan)

4. Modal

- Asal modal awal, modal awal yang di gunakan usaha industri tahu.

- Jumlah modal yang digunakan dinyatakan dalam (Rp)

5. Biaya produksi yaitu besarnya biaya yang di keluarkan pada usaha industri tahu tempe

- Biaya penyusutan alat alat produksi (Rp/bulan)

- Biaya bahan baku (Rp/kg)

- Biaya bahan penolong (Rp/bulan)

- Biaya tenaga kerja (Rp/bulan)

- Biaya bahan bakar (Rp/bulan) 
3. Mekanisme Pemasaran

- cara penjualan, proses penyaluaran dari produsen ke konsumen

- penetapan harga

4. Keuntungan merupakan, penerimaan di kurangi dengan biaya yang di keluarkan. Dinyatakan dalam rupiah/bulan

\section{Analisis Data}

Teknis analisis data yang digunakan dalam penelitian ini adalah analisis secara deskriptif dimana data yang terkumpul akan disajikan dalam bentuk Tabel.

\section{KEADAAN UMUM DAERAH PENELITIAN}

\section{Keadaan Wilayah}

Kecamatan Malalayang terletak di sebelah barat kotaManado. Memiliki luas wilayah $\pm 1654 \mathrm{Ha}$, dengan jumlah penduduk sekitar 45.733 jiwa. Kecamatan Malalayang memiliki 8 kelurahan yaitu Kelurahan Malalayang I, Kelurahan Malalayang II, Kelurahan Malalayang I Timur, Kelurahan Malalayang I Barat, Kelurahan Bahu, Kelurahan Kleak, Kelurahan Batu Kota, dan Kelurahan Winangun. Kecamatan Malalayang terletak di sebelah barat kota Manado. Jarak antara Kecamatan Malalayang dengan ibu kota Propinsi yaitu kurang lebih $10 \mathrm{~km}$. Adapun batas-batas wilayah Kecamatan Malalayang adalah sebagai berikut :

a. Sebelah Utara berbatasan dengan kecamatan Sario

b. Sebelah Timur berbatasan dengan kecamatan Pineleng

c. Sebelah Selatan berbatasan dengan kecamatan Pineleng

d. Sebelah Barat berbatasan dengan Laut Manado.

\section{Gambaran Umum Kelurahan Bahu}

\section{Letak dan Luas Wilayah}

Kelurahan Bahu merupakan salah satu kelurahan yang berada di Kecamatan
Malalayang, terletak pada ketinggian 5-7 mdpl dengan batas-batas wilayah sebagai berikut :

a. Sebelah Utara dengan Kelurahan Sario Utara

b. Sebelah Timur dengan Kelurahan Sario

c. Sebelah Selatan dengan Kelurahan Kleak

d. Sebelah Barat dengan Kelurahan Malalayang I Timur.

\section{Penduduk}

Kelurahan Bahu memiliki Jumlah penduduk sekitar 7121 jiwa,dengan 1741 kepala keluarga, terdiri dari sekitar 3325 jiwa penduduk laki-laki dan 3796 jiwa penduduk perempuan.

\section{Mata Pencaharian}

Sebagian besar penduduk di Kelurahan Bahu memiliki mata pencaharian sebagai Pegawai Negeri Sipil. Sendangkan mata pencaharian lainnya adalah di bidang pertanian, perkebunan, peternakan, perdagangan, jasa angkutan, dan jasa lainnya. Untuk lebih jelas dapat di lihat pada Tabel 2.

Tabel 2. Jenis Mata Pencaharian Penduduk di Kelurahan Bahu Kecamatan Malalayang

\begin{tabular}{llc}
\hline No. & Jenis Mata Pencaharian & $\begin{array}{c}\text { Presentase } \\
(\boldsymbol{\%})\end{array}$ \\
1. & Pegawai Negeri Sipil (PNS) & 35,36 \\
2. & Karyawan Swasta & 18,11 \\
3. & Pensiunan & 5,19 \\
4. & Pertukangan & 3,63 \\
5. & Nelayan & 3,58 \\
6. & Wiraswasta & 3,25 \\
7. & Petani & 0,16 \\
8. & Jasa Lainnya & 30,70 \\
\hline \multicolumn{2}{l}{ Total } & 100 \\
\hline \multicolumn{2}{l}{ Sumber :Data Profil Kelurahan Bahu (2016) }
\end{tabular}

Tabel 2 menunjukan bahwa sebagian besar penduduk di kelurahan Bahu bermata pencaharian sebagai Pegawai Negeri Sipil yaitu sebanyak 35,36 persen dari keseluruhan penduduk di kelurahan bahu kecamatan Malalayang. 


\section{HASIL DAN PEMBAHASAN}

\section{Gambaran Proses Produksi}

\section{Produksi Tahu}

Proses produksi merupakan teknis untuk menghasilkan atau menambah kegunaan suatu barang atau jasa dengan sumber-sumber yang tersedia seperti matrial,tenaga kerja, modal dan teknologi. proses pembuatan tahu memerlukan beberapa alat dan bahan seperti alat yang digunakan dalam proses pembuatan tahu meliputi mesin penggiling, mesin pompa air wajan, pisau ember alat pencetak tahu. Bahan yang digunakan dalam pembuatan tahu yaitu solar,kain saring, kemasan plastik, bahan pengencer cuka, kedelai. Adapun proses pembuatan tahu dapat di lihat pada gambar 1 .

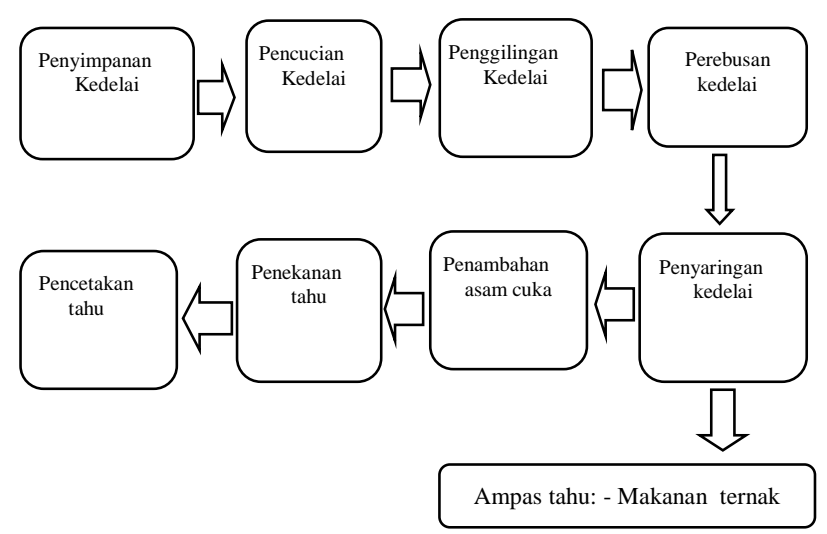

\section{Gambar 1. Proses Pembuatan Tahu}

Gambar 1 menunjukan bahwa proses pembuatan TahuX yaitu :

1. $50 \mathrm{~kg}$ kedelai yang akan digunakan dibersihkan dengan cara di rendam menggunakan air yang bersih selama 8 jam. Dalam proses perendaman ini kedelai akan mengembang. Bersihkan kedelai dengan cara dicuci berkali-kali.

2. Kedelai yang teleah di rendam selama 8 jam kemudian dibersihkan dengan cara dicuci berulang-ulang tiga 3-4 kali sampai benar-benar bersih.

3. Setelah kedelai dibersihkan, kemudian kedelai dihancurkan menggunakan mesin penggiling hingga berbentuk bubur

4. Setelah kedelai sudah di hancurkan hingga berbentuk bubur,kemudian kedelai di masak.
Dalam proses perebusan bubur kedelai tidak boleh terlalu kental kemudian dalam proses perebusan bubur kedelai ditandai dengan adanya gelembung-gelembung kecil.

5. Kemudian kedelai yang telah masak di angkat dari wajan dan disaring menggunakan kain penyaring dengan menggunakan asam cuka sambil terus di aduk secara perlahan, hingga bubur kedelai menggumpal

6. Dari gumpalan tahu yang telah di tambahkan asam cuka siap di press yang berfungsi untuk menekan ampas agar kandungan airnya benarbenar habis.

7. Setelah gumpalan tahu di press, tahu kemudian di cetak segi empat dengan komposisi tiap satu papan cetakan bias mengisi setengah ember .jadi untuk mengisi tiap ember diperlukan dua papan cetakan tahu. Tiap ember berisi kurang lebih 230 potong tahu.

Langka-langkah pembuatan tahu di Industri Tahu Tempe X masih sangat sederhana dengan penggunaan alat-alat masih tradisional. Dalam proses pembuatan tahu masih di kerjakan oleh manusianya, hanya sedikit menggunakan teknologi seperti penggunaan mesin penggiling.

\section{Produksi Tempe}

Proses pembuatan tempe dapat di lihat pada Gambar 2.

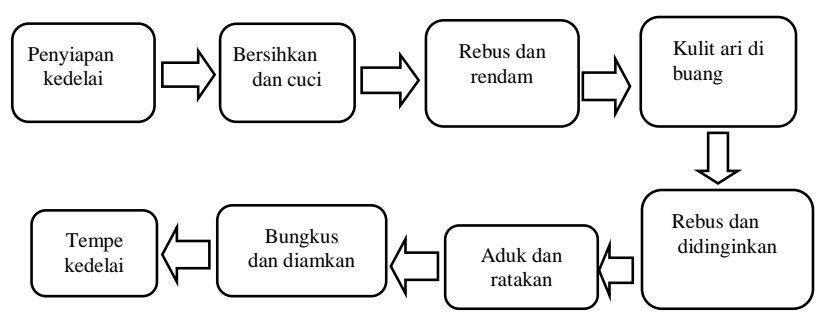

\section{Gambar 2 Proses Pembuatan Tempe}

Gambar 2 menunjukan bahwa proses pembuatan Tempe $\mathrm{X}$ yaitu :

1. Pilih kedelai yang berkualitas baik, lalu di bersihkan dan dicuci dengan air bersih

2. Setelah bersih kedelai di rebus selama kurang lebih 30-40 menit sampai kedelai yang dihasilkan benar-benar lunak, kemudian direndam selama 22-24 jam setelah perebusan

3. setelah semalam direndam dalam air perebus kulit ari kedelai $\mathrm{d}$ buang 
4. kedelai yang telah dibuang kulitnya di rebus lagi dengan air bersih. Perebusan di lakukan selama 90 menit. Sampai titik didih tercapai kemudian rebusan kedelai di cuci untuk memisahkan kulit kedelai dengan menggunakan saringan dan di keringkan dengan menggunakan bantuan kipas angin selama 1-2 jam

5. Dan dicampur dengan ragi 2 sendok makan di aduk secara merata kemudian di siapkan pembungkusnya

6. Kedelai yang sudah dicampur di bungkus dengan plastik terlebih dahulu harus di cetak agar tempe yang di hasilkan lebih rapih. Kedelai yang telah dibungkus disusun dengan rapih pada rak fermentasi.

7. Proses ini berlangsung selama 44-48 jam atau kurang lebih 2 hari tempe kedelai sudah jadi.

\section{Karakteristik Pengusaha}

\section{Umur}

Pengusaha Tahu dan Tempe berumur 40 tahun, merupakan umur produktif dalam berusaha. Akan tetapi umur tersebut tidak mempengaruhi besar atau kecilnya produksi yang dihasilkan.

\section{Tingkat Pendidikan}

Sebenarnya faktor pendidikan dapat mempengaruhi pola berfikir pengusaha, untuk mengelola atau menjalankan usaha tersebut. Pengusaha Tahu dan Tempe ini berpendidikan SMA.

\section{Jumlah Tanggungan.}

Jumlah tanggungan berjumlah 3 orang terdiri dari istri dan anak-anak, ditambah dengan keluarga lainnya yang menetap di kediamannya, termasuk pekerja di usahanya.

\section{Menurut Lama Usaha}

Pengrajin menjalankan usahanya sudah 14 tahun. Suatu jangka berusaha yang panjang dengan pengalaman yang banyak.

\section{Produksi}

Hasil penelitian menunjukan bahwa dalam melakukan produksi, pengusaha menggunakan kedelai jenis impor sebagai bahan baku utama, hal ini disebabkan karena kedelai impor memiliki kualitas yang lebih baik daripada kedelai lokal. Untuk melakukan proses produksi, jumlah kedelai yang di pergunakan yaitu sebanyak $100 \mathrm{~kg}$ dan $50 \mathrm{~kg}$ di gunakan untuk produksi Tempe (100 biji), dan $50 \mathrm{~kg}$ digunakan untuk produksi Tahu (6.900 buah), maka setiap bulannya pengusaha tersebut harus menyediakan kedelai kurang lebih 3 ton, dengan harga kedelai sebesar Rp. $7.500 / \mathrm{kg}$. Dari proses produksi tersebut kedelai yang terpakai dalam sebulan kurang lebih $3.000 \mathrm{~kg}$, sendangkan sisanya menjadi ampas tahu yang dijual Rp 10.000/karung. Hasil sampingan dari produk tahu tempe berupa ampas yang mempunyai nilai ekonomi yang di gunakan sebagai bahan makanan ternak. Tiap kali $100 \mathrm{Kg}$ kedelai yang dimasak, menghasilkan ampas tahu sebanyak 5 karung. Ampas tersebut di jual dengan harga $\mathrm{Rp}$. 10.000/karung.

\section{Penggunaan Faktor Produksi}

\section{Biaya Produksi}

Biaya (cost) adalah hasil dari semua input ekonomi yang diperlukakan dan dapat diperkirakan untuk menghasilkan suatu produk atau nilai yang dinyatakan dengan uang dalam satuan rupiah (Rp). Mulyadi (2007), mengemukakan bahwa biaya merupakan pengorbanan yang diuykur dengan satuan uang yang dilakukan untuk mencapai tujuan tertentu. Ada dua jenis biaya pada industri Rumah tangga Tahu dan Tempe $\mathrm{X}$ di Kelurahan Bahu Kecamatan Malalayang yaitu biaya variabel (variable cost) dan biaya tetap (fixed cost).

\section{Biaya tetap (Fixed Cost)}

Biaya tetap (FC) yang dimaksud dalam penelitian ini adalah biaya yang tidak habis dalam satu kali proses produksi tetapi hanya mengalami penyusutan atau yang disebut sebagai biaya investasi seperti pengadaan peralatan. Untuk menunjang keberlangsungan industri pembuatan Tahu 
Tempe X di perhitungkan sebagai penyusutan kerja dari alat-alat produksi yang digunakan dalam memproduksi tahu. Penyusutan dapat dihitung berdasarkan umur ekonomis dari alat-alat produksi. Untuk mengetahui nilai ekonomis dari masing-masing peralatan yang digunakan dalam proses produksi Tahu Tempe $\mathrm{X}$, maka dihitung penyusutannya dalam satu kali produksi. Penyusutan dihitung dengan menggunakan metode garis lurus yaitu nilai awal dari peralatan dikurangi dengan nilai sisa kemudian dibagi dengan umur ekonomis dari peralatan tersebut. Nilai awal diperoleh dari biaya yang digunakan untuk membeli peralatan tersebut sendangkan umur ekonomis dilihat dari lamanya penggunaan peralatan tersebut masih menguntungkan.Untuk lebih jelasnya mengenai penyusutan biaya tetap dalam penelitian ini dapat dilihat dalam Tabel 3.

\begin{tabular}{lll} 
Tabel & 3. Biaya tetap yang digunakan \\
& Indsutri & \multicolumn{2}{c}{ Rumah } & tangga & Tahu \\
& Tempe X di Kelurahan & Bahu \\
\multicolumn{4}{c}{ Kecamatan Malalayang } \\
\hline No. & Komponen Biaya & $\begin{array}{l}\text { Penyusutan } \\
\text { (Rp/bln) }\end{array}$ \\
1. & Mesin Penggiling & 8.750 .000 \\
2. & Mesin Pompa Air & 1.488 .000 \\
3. & Wajan & 3.750 .000 \\
4. & Pisau & 1.104 .000 \\
5. & Ember & 287.000 \\
6. & Alat Pencetak Tahu & 2.450 .000 \\
7. & Pajak/Tahun & 83.333 \\
\hline \multicolumn{3}{c}{ Jumlah } \\
\hline
\end{tabular}

Biaya tetap yang digunakan industri Tahu Tempe $X$ di Kelurahan Bahu Kecamatan Malalayang terdapat 7 (tujuh ) komponen biaya yang digunakan. Dalam proses produksi Tahu dan Tempe dari yang tertinggi sampai yang terendah biaya yang digunakan yaitu Mesin penggiling, mesin pompa air, wajan, pisau, ember, alat pencetak tahu dan pajak/tahun. jumlah keseluruhan biaya penyusutan industri Tahu Tempe $\mathrm{X}$ adalah sebesar Rp.17.912.333/bulan. untuk lebih jelasnya dapat dilihat pada lampiran 2 .

\section{Biaya variabel (variable cost)}

Biaya variabel cost yang di maksud dalam penelitian ini adalah biaya yang habis terpakai dalam satu kali siklus produksi pada industri Tahu Tempe X biaya variabel adalah biaya yang jumlah totalnya sebanding dengan perubahan volume kegiatan. Biaya variabel per unit konstan tetapi semakin besar volume kegiatan semakin besar pula biaya totalnya. Selanjudnya penggunaan biaya variabel pada indutri Tahu Tempe $\mathrm{X}$ dapat dilihat pada Tabel 4.

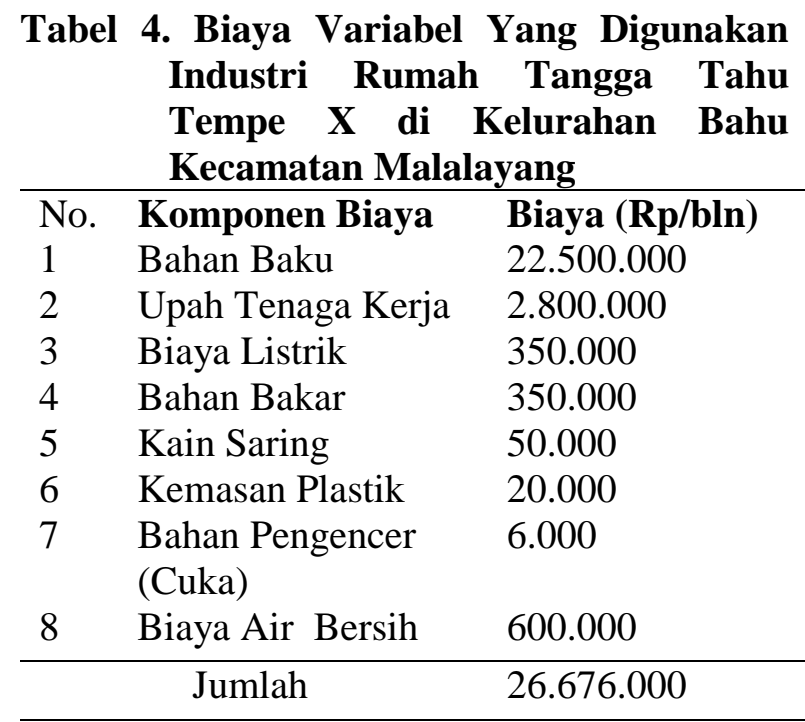

Sumber : Diolah dari dapa Primer (2016)

Proses produksi untuk menghasilkan output tidak terlepas dari biaya. Biaya usaha Indutri Rumah Tangga Tahu Tempe X merupakan biaya yang dikeluarkan oleh industri dalam melakukan kegiatan usahanya atau biaya yang dikeluarkan industri selama melakukan proses produksi. Sehingga besar kecilnya biaya yang dikeluarkan indutri Rumah tangga Tahu Tempe mempengaruhi produksi seperti bahan baku, tenaga kerja, bahan pengencer (cuka), kain saring, bahan bakar, kemasan plastic. Dari data Tabel 4 menunjukan bahwa yang tertinggi dari pembuatan Tahu Tempe X selama satu bulan sebesar Rp.22.500.000/bulan. Untuk pembelian bahan baku, sendangkan biaya terendah adalah pada biaya pembelian bahan pengencer (cuka) yang berkisar hanya sekitar 
Rp 6.000. Total biaya variabel yang di keluarkan oleh Industri Rumah tangga Tahu Tempe X di Kelurahan Bahu Kecamatan Malalayang adalah Rp.26.676.000/bulan.

\section{Biaya total (Total Cost)}

Biaya total atau (total cost) adalah jumlah dari biaya tetap dan biaya variabel. biaya total yang di gunakan industri Tahu Tempe X di Kelurahan Bahu Kecamatan Malalayang di lihat pada Tabel 5.

\begin{tabular}{lr} 
Tabel 5. Biaya total yang digunakan \\
\\
$\begin{array}{lr}\text { industri Tahu dan Tempe di } \\
\text { Kelurahan Bahu Kecamatan } \\
\text { Malalayang }\end{array}$ \\
\hline Biaya & Jumlah (Rp) \\
Biaya Tetap & 17.912 .333 \\
Biaya Variabel & 26.676 .000 \\
\hline Total & 44.588 .333 \\
\hline
\end{tabular}

Tabel 5 menunjukan bahwa nilai total biaya tetap yang dikeluarkan oleh Industri Tahu dan Tempe $\mathrm{X}$ adalah sebesar $\mathrm{Rp}$. 17.912.333 dan nilai total biaya variabel sebesar 26.676.333 dari kedua biaya tersebut, biaya tertinggi adalah biaya variable. Disebabkan karena jumlah pemesanaan bahan baku lebih besar.

\section{Harga}

Harga yang dikeluarkan oleh industri rumah tangga Tahu Tempe $\mathrm{X}$ di Kelurahan Bahu Kecamatan Malalayang praktis tidak mengalami perubahan. Industri rumah tangga Tahu Tempe $\mathrm{X}$ menjual produk Tahunya denganharga 250/potong. Rata-rata harga jual yang berlaku dipasaran adalah sama. Jumlah tahu yang di produksi dalam satu hari adalah sebanyak 30 ember, dimana dalam satu ember terdapat 230 potong tahu.Sedangkan harga jual untuk tempe yaitu Rp. 2.000/potong.

\section{Penerimaan}

Kegiatan usaha yang dilakukan oleh seseorang akan menghasilkan suatu penerimaan yang diterima dalam hal ini
Indutri Tahu Tempe $\mathrm{X}$. Penerimaan yang dimaksud dalam penelitian ini adalah perkalian antara produksi yang diperoleh dengan harga jual.

Tabel 6. Jumlah Produksi yang di Hasilkan Industri Tahu Tempe $X$ di Kelurahan Bahu Kecamatan Malalayang

\begin{tabular}{llclc}
\multicolumn{6}{l}{ a. Produksi Tahu dan Ampas Tahu } & \\
\hline Jenis & $\begin{array}{c}\text { Jumlah } \\
\text { Produksi }\end{array}$ & Satuan & $\begin{array}{c}\text { Harga } \\
\text { Satuan } \\
(\mathrm{Rp})\end{array}$ \\
\hline Tahu & Hari & 6.900 & Potong/Hari & 250/Potong \\
& Bln & 207.000 & Potong/Bulan & \\
& Hari & 5 & Karung/Hari & \\
Ampas & Bln & 150 & Karung/Bulan & 10.000 \\
& & & &
\end{tabular}

\begin{tabular}{|c|c|c|c|c|}
\hline \multicolumn{5}{|c|}{ b. Produksi Tempe } \\
\hline $\begin{array}{l}\text { Jumlah } \\
\text { Produksi }\end{array}$ & Satuar & & $\begin{array}{c}\text { Harga } \\
\text { Satuan (Rp) }\end{array}$ & Penerimaan \\
\hline $\begin{array}{c}\text { Hari } \\
\text { Bulan }\end{array}$ & $\begin{array}{l}100 \\
3.000\end{array}$ & Biji & 2.000 & $\begin{array}{c}200.000 \\
6.000 .000\end{array}$ \\
\hline
\end{tabular}

Tabel 6 menunjukan bahwa produksi tahu dalam satu hari yaitu 6.900 potong dengan jumlah penerimaan sebesar Rp.1.725.000. Sedangkan penerimaan dari ampas tahu sebesar Rp.50.000 dalam satu hari. Produksi tempe pada tabel di atas menjelaskan bahwa jumlah produksi tempe dalam satu hari sebanyak 100 biji dengan penerimaan sebesar Rp.200.000. Hasil penelitian menunjukan bahwa dalam melakukan produksi, pengusaha menggunakan kedelai jenis impor sebagai bahan baku utama,hal ini disebabkan karena kedelai impor memiliki kualitas yang lebih baik daripada kedelai lokal. Selama melakukan proses produksi jumlah kedelai yang di pergunakan yaitu sebanyak $100 \mathrm{~kg}$. $50 \mathrm{~kg}$ digunakan untuk produksi tempe $(3.000$ biji/bulan) dan $50 \mathrm{~kg}$ digunakan untuk produksi tahu (6.900 potong/bulan ), maka setiap bulannya pengusaha tersebut harus menyediakan kedelai kurang lebih $3.000 \mathrm{~kg}$ atau 3 ton. Dengan harga kedelai 7.500/kg.Sendangkan sisanya menjadi ampas tahu yang di jual Rp 10.000/karung. Sehingga 
penerimaan dalam satu bulan proses produksi pada industri Tahu Tempe X di Kelurahan Bahu Kecamatan Malalayang adalah Rp.59.250.000/bulan.

\section{Keuntungan}

Keuntungan merupakan selisih antara penerimaan dan semua biaya total produksi yang dikeluarkan oleh Industri Tahu Tempe $X$ .keuntungan yang diterima industri Tahu Tempe tentunya telah di kurangi dengan semua biaya yang digunakan pada saat proses produksi Tahu Tempe yang dihasilkan.

\section{Tabel 7. Keuntungan yang dihasilkan Industri} Tahu Tempe X di Kelurahan Bahu Kecamatan Malalayang

\begin{tabular}{llc}
\hline No. & Uraian & Jumlah \\
1. & Penerimaan & 59.250 .000 \\
2. & Biaya & 44.588 .333 \\
3. & Keuntungan & 14.661 .667 \\
\hline
\end{tabular}

Industri Tahu Tempe X Dalam proses produksi serta pemasaran Tahu Tempe menghasilkan penerimaan dalam satu bulan Rp.59.250.000/bulan. Dalam proses ini penerimaan yang diterima cukup tinggi sendangkan total biaya yang digunakan cukup efisien. Dari Tabel 7 dapat di ketahui bahwa penerimaan yang di peroleh usaha Industri Tahu Tempe $\mathrm{X}$ dalam satu bulan proses produksi yaitu sebesar Rp.59.250.000/bulan, sendangkan biaya total yang digunakan dalam satu bulan proses produksi sebesar Rp.44.588.333/bulan. Dari kedua biaya tersebut yang memiliki jumlah tertinggi total penerimaan dibandingkan dengan biaya total yang digunakan pada Industri Tahu Tempe $\mathrm{X}$ sehingga diketahui keuntungan yang diperoleh industri Tahu Tempe $X$ dalam satu bulan sebesar Rp.14.661.667.

\section{KESIMPULAN}

\section{Kesimpulan}

Kesimpulan dari penelitian menunjukkan bahwa Industri Tahu Tempe $\mathrm{X}$ mengalami keuntungan, dimana total penerimaan yang diterima sebesar Rp.59.250.000 per bulan dikurangi dengan total biaya yang dikeluarkan sebesar
Rp.44.588.333. Maka keuntungan yang diterima adalah sebesar Rp.14.661.667.

\section{Saran}

Kepada Industri Tahu Tempe X diharapkan tetap mempertahankan keuntungan yang di peroleh dengan cara lebih memperhatikan persediaan bahan baku agar mendapatkan hasil yang lebih optimal. Di perlukan peran yang serius dari pemerintah agar dapat membantu para pengusaha industri rumah tangga tahu dan tempe, agar para pengusaha bisa meningkatkan jumlah produksinya.

\section{DAFTAR PUSTAKA}

Amang, 1996. Ekonomi Kedelai di Indonesia. IPB Press. Bogor

Ambarwati, S. R. R.1994. Beberapa Aspek Ekonomi pada Industri Tahu dan Tempe,Studi Kasus Industri Tahu dan Tempe di Kecamatan Parung Kabupaten Bogor.

David Downey, W dan Steven P. E. 1992. Manajemen

Agribisnis.Erlangga.Jakarta

Dhakidae, 1997.Teknologi, Prisma No. 6

Djojodipura, 1991. Teori Harga. Lembaga Penerbit Fakultas ekonomi, Universitas Indonesia. Jakarta.

Hernant, D. F. 1991. Ilmu Usaha Tani. Penerbit Swadaya.Jakarta

Haryono, J. 1997 Dasar2 akuntansi .STIE YKPN Universitas Gadjah Mada,Yogyakarta.

Kotler, P. 1991. Manajemen Pemasaran. Erlangga. Jakarta

Manullang, M. 1991. Pengantar Ekonomi Perusahaan. Liberty. Yogyakarta 
Mubyarto, 1991. Pengantar Ekonomi Pertanian. LP3ES. Jakarta

Nor Rahmawatiy, 2001. Potensi Dan Peluang Pengembangan Industri Tahu Dan Tempe di Kota Manado.Skripsi. Universitas Sam Ratulangi. Manado.

Salahudin, S.1998. Visi Pembangunan Pertanian

Santoso, B. H. 1993. Pembuatan tempe dan tahu kedelai bahan makanan bergizi tinggi. Kanisius. Yogyakarta.
Soekartawi, 1991.Agribisnis Teori dan Aplikasinya.Universitas Indonesia. Jakarta

T 1995. Analisis Usaha Tani.Universitas Indonesia. Jakarta

Tatuh, J. 1994.Dimensi Teknologi Dalam Pembangunan Pertanian pada PJPT II(Makalah Seminar). Universitas Sam Ratulangi. Manado. 